\title{
RESOURCE CURSE AND EITI MEMBERSHIP EFFECT ON THE ECONOMIC GROWTH AND CORRUPTION IN SUB-SAHARAN AFRICA: PART II - AN EMPIRICAL ANALYSIS
}

\author{
Andries Francois Geldenhuys ${ }^{1}$, Oluseye Samuel Ajuwon ${ }^{2 *}$ \& Michael Graham ${ }^{1}$ \\ ${ }^{1}$ Business School, Stellenbosch University, Western Cape, South Africa \\ ${ }^{2}$ Department of Economics, University of Lagos, Lagos, Nigeria \\ fgeldenhuys46@gmail.com \\ aajuwon@unilag.edu.ng \\ michael.graham@usb.ac.za
}

\begin{abstract}
This study is the second and concluding part of the study that feature in volume 5(1) of this journal. It examines the impact of the Extractive Industries Transparency Initiative (EITI) membership on Economic Growth and corruption in Sub-Saharan Africa (SSA). A pooled cross-sectional panel study on 46 countries in SSA from 1996 to 2016 was employed. The results show that EITI membership and its statistical interaction with resource dependence have a moderately positive effect on reducing the resource curse on implementing countries by increasing GDP per capita. However, the results do not indicate any significant reduction in the level of corruption associated with governance in the region through EITI membership. The research concludes that the EITI has potential value and should continue to be used as a mechanism to increase transparency in the resource-curse economy. The implementation period for most member countries is, however, still in its infancy and it will be possible to assess the more success of the EITI membership with the passage of time.
\end{abstract}

Keywords: Extractive Industries Transparency Initiative (EITI), corruption, transparency, resource curse, economic growth

JEL Classification: 013

\section{Introduction}

This study is to determine if natural resource information disclosure to civil society organisations, through EITI membership, will increase economic growth, and impact corruption positively in sub-Saharan African Countries. The question of what distinguishes resource-rich states, like Norway (oil) and Botswana (diamonds), from basket-case economies (economy characterized by high level of unemployment, and all economic woes), like Venezuela (oil) and Sierra Leone (diamonds), has been investigated in the literature. The extant studies suggest that corruption, which is highly susceptible in extractive industries, plays a prominent role in explaining the divergent fortunes of such resource-rich states (Fisman and Golden, 2017).

\section{Hypotheses}

The hypotheses and the a-priori expectations examined in this study, based on Corrigan (2013), are as follows:

- $\quad \mathrm{H}_{1}$ : Natural resource information disclosure to civil society organisations, through EITI membership, will increase economic growth, depending on resource endowment in a member country.

\footnotetext{
* Corresponding author: Oluseye Samuel Ajuwon
} 
- $\quad \mathrm{H}_{2}$ : Natural resource information disclosure to civil society organisations, through EITI membership, will reduce corruption, depending on resource endowment in a member country.

This paper contributes to the literature on whether transparency, through collective action, is an effective tool to curb corruption and consequently improve economic growth. Evidence of the EITI's impact on corruption is still mixed. David-Barret and Okamura (2013) found that corruption scores of implementing countries improved after signing up to the standard. However, this was contradicted by Kasekende, Abuka and Sarr (2016), who found no evidence to support the relationship. There are limited studies on the effect of EITI membership on economic growth and corruption, with the only cross-country study achieving mixed results. The Corrigan (2013) study examined 200 countries from 1995 to 2009, and found that EIT-implementing countries mitigated the negative effect of resource abundance on GDP per capita, sound policy formation and rule of law, but showed insignificant effects on democracy, political stability and corruption. This study lends credence to the study by Corrigan (2013), in extending the dataset period as well as focusing only on African countries where the issue of resource curse is well pronounced. We find that EITI membership and its statistical interaction with resource dependence have a moderately positive effect on reducing the resource curse on implementing countries by increasing GDP per capita. However, the results do not indicate any significant reduction in the level of corruption associated with governance in the region through EITI membership. The rest of the paper is structured as follows: Section 2 presents the literature review in brief (for complete literature review, see Geldenhuys, Ajuwon, and Graham (2020)). Section 3 outlines the methodology employed in the study. Section 4 provides a discussion of the findings, while section 5 concludes the study.

\section{Literature Review}

\subsection{Theoretical Literature Review}

\subsubsection{Resource Curse}

Theoretical literature distinguishes between the direct and indirect effects of natural resources on economic growth. The direct effect, commonly known as Dutch disease, relates to an appreciation in the real exchange rate of a country due to the inflow of substantial amounts of foreign currency (Sachs and Warner, 2001). This appreciation establishes equilibrium in the labour and non-traded goods market as increased disposable income raises the wages in the non-traded goods sector and increases the demand for non-traded goods. The traded non-resource goods sector loses competitiveness as it is partially crowded out (spending effect) (Leite and Weidmann, 1999). Secondly, the increased wages in the resource sector during a resource boom pull capital and labour away from other sectors (resource pull effect) (Leite and Weidmann, 1999). Entrepreneurial activity and innovation are crowded out by sectoral wage levels as labour gravitates to the resource sector (Sachs and Warner, 2001). The indirect effect is manifested in rent-seeking governance (Leite and Weidmann, 1999).

\subsubsection{Corruption and Economic Growth}

The theoretical literature offers two contrasting views on the effect of corruption on economic growth; the grease the wheels and sand the wheels hypotheses. The grease the wheels hypothesis states that corruption can negate the negative effect of an inefficient bureaucracy and excessive red tape, increasing economic efficiency (Leff, 1964; Huntington, 1968). However, this view contrasts with the sand the wheels hypothesis, whereby corruption reduces economic efficiency and has a detrimental effect on economic growth (Méon and Sekkat, 2005). 


\subsubsection{Transparency and Corruption}

The use of transparency initiatives is viewed as a key element in the fight against corruption in resource-rich states (Kolstad and Wiig, 2008). These initiatives seek in general to improve the sanctioning mechanisms through which civil society can hold governments to account and enhance the development outcomes when natural resources are abundant (Mejía Acosta, 2013). Transparency is expected to open the lines of communication, allow scrutiny of government rents and theoretically incentivise governments to invest in pro-development policies (Corrigan, 2013; Nwapi, 2014). Traditional transparency theory is based on a simplistic model that assumes that information released will produce an engaged and informed citizenry that is motivated to hold government to account (Fenster, 2005).

\subsection{Empirical Literature Review}

\subsubsection{Resource Curse}

The debate on whether natural resource abundance is detrimental to economic growth was ignited by a seminal paper by Sachs and Warner (1995). The authors argued that there is an inverse relationship between natural resource intensity and economic growth. The finding was based on cross-country growth regressions for 95 developing countries from 1970 to 1990. This theory was expanded by Sachs and Warner (2001), who tested the same data set for omitted geographical and climate variables. Little direct evidence was found that climate and geography explained the curse, and the "Dutch disease" hypothesis was strengthened by the tendency of resource-abundant countries to be high-priced economies. These findings were supported by Karl (1997) and Ross (1999), who found that oil-rich countries have declining income per capita and displayed lower development outcomes.

\subsubsection{Corruption and Economic Growth}

The empirical evidence on the detrimental effect of corruption on economic growth has largely reached consensus and rejected the "grease the wheels" argument in favour of the "sand the wheels" hypothesis. Cross-country data indicates that corruption is consistently correlated with lower growth and lower GDP per capita (Rothstein and Holmberg, 2011). The theoretical arguments of the negative effect of corruption on economic growth through lower levels of investment, lower quality of investments, high indirect taxation and the misallocation of resources are largely supported by empirical studies (Dimant and Tosato, 2018).

\subsubsection{Transparency and Corruption}

The empirical literature shows that increased transparency can reduce corruption, albeit with some caveats, and that transparency on its own does not automatically lead to increased accountability and reduced corruption. Islam (2006), observing 169 countries from 1984 to 1997, found that increased information flows (higher transparency) on economic data led to better governance indicators. Bauhr, Grimes and Harring (2010) found that increased transparency generated different reactions in countries with higher levels of corruption to those with lower levels. In highly corrupt countries, transparency erodes political trust but stimulates civic engagement. The incitement of civic discontent in the short term is however mitigated by greater accountability and better governance in the long term. Corrigan (2013) investigated the influence that membership of the EITI has on economic development and quality of governance, including an indicator for levels of corruption. Using OLS regressions on pooled cross-sectional panel data for 200 countries from 1995 to 2009, the author found that institutional transparency mitigated the resource curse with reference to GDP per capita, facilitated limited improvement in corruption and accountability measures and showed no improvement in stability and violence indicators. To date this is the only 
study that has investigated the effect of institutional transparency, through EITI membership, on the resource curse and corruption in resource-rich states.

\section{Data and Methodology}

\subsection{Data}

The EITI has 51 implementing countries as of 2018, of which 24 are from SSA (EITI, 2017). In this paper, we include all the 46 countries classified as SSA based on the World Bank's regional definition. The annual data used covered the period 1986 to 2016 (31 observations).

\subsubsection{Dependent variables}

The dependent variable for economic growth $\left(\mathrm{H}_{1}\right)$ is GDP per capita. Economic growth was chosen to determine whether the standard is merely political posturing or a policy directive that increases wellbeing in resource-rich economies.

The dependent variable for corruption $\left(\mathrm{H}_{2}\right)$ is the control of corruption measure of the World Governance Indicators (WGI) as developed by Kaufman, Kraay and Mastruzzi (2010). The WGI measures score countries on a scale from -2.5 to 2.5 on a yearly basis, based on six governance indicators: voice and accountability (democracy), political stability/no violence (stability and absence of conflict), government effectiveness (public service quality), regulation quality (policy quality), rule of law (predictability of law measures, property rights) and control of corruption (corruption perception measure). This study only focused on the control of corruption measures, as they are the strongest indicator of the prevalence of rent-seeking in the natural resource sector and align strongly with the central aims of the EITI.

\subsubsection{Independent variables}

The independent variables are the same for $\mathrm{H}_{1}$ and $\mathrm{H}_{2}$. The first independent variable is membership of the EITI. The dataset, as can be seen in Table A1 of Appendix 1, was constructed from qualitative data found in timelines disclosed on the EITI webpages for individual members (EITI, 2018). EITI membership is incorporated through a dummy variable, where membership for SSA countries in a specific year is assigned a "1" if they were a member, or " 0 " if they were not. One of the key assumptions in determining the variable for EITI membership (EITI_MEM) is the date on which countries become members. In this research assignment, membership is based on the year that the country signalled its intent to join the EITI. This enables the dataset to be expanded for the period of accreditation, which can take between one and seven years, as can be seen in Table A1. This also takes into the account the signalling effect of the country demonstrating its willingness to commit to transparent resource governance and to work towards EITI membership (Corrigan, 2013).

The second independent variable is a proxy for natural resource endowment. This is important as the EITI is specifically focused on resource-rich countries, and this study aims to address the effect the EITI has on the natural resource "curse". The variable RES measures the resource dependence of a country: primary exports to total merchandise exports as published by the United Nations Conference on Trade and Development, with high resource dependence being indicated by a high ratio of primary exports to total merchandise exports (see Table 1).

\subsubsection{Control variables}

Separate control variables are used in both hypotheses and aim to reduce the omitted variable bias. These control variables are known to correlate with the dependent variables. 
For $\mathrm{H}_{1}$ : inflation (annual consumer inflation), investment (gross capital formation as percentage of GDP), government consumption (general government final consumption), democracy levels (PolitylV score), population (total population) and trade openness (imports and exports as percentage of GDP). For $\mathrm{H}_{2}$ : population, negative GDP-per-capita growth and government consumption are used as control variables (see Table 1).

Table 1: Data variables and sources

\begin{tabular}{|c|c|c|}
\hline Reference & Description & Sources \\
\hline \multicolumn{3}{|l|}{$\begin{array}{l}\text { Dependent } \\
\text { variables }\end{array}$} \\
\hline GDPPC & $\begin{array}{l}\text { Gross Domestic Product per capita } \\
\text { (constant } 2010 \text { US\$) }\end{array}$ & $\begin{array}{l}\text { World Bank Development } \\
\text { Indicators }\end{array}$ \\
\hline $\mathrm{CoC}$ & Control of Corruption & $\begin{array}{l}\text { The World Governance Indicators } \\
\text { (Kauffman et.al., 2010) }\end{array}$ \\
\hline \multicolumn{3}{|l|}{$\begin{array}{l}\text { Independent } \\
\text { variables }\end{array}$} \\
\hline EITImem & $\begin{array}{l}\text { Dummy variable for EITI membership } \\
\text { (1=intension, } 0=\text { no intension) }\end{array}$ & EITI website \\
\hline RES & $\begin{array}{l}\text { Resource dependence proxy (primary } \\
\text { exports/merchandise exports) }\end{array}$ & $\begin{array}{l}\text { United Nations Conference on } \\
\text { Trade and Development (UNCTAD) }\end{array}$ \\
\hline \multicolumn{3}{|l|}{ Control variables } \\
\hline INVEST & Gross capital formation (\% of GDP) & $\begin{array}{l}\text { World Bank Development } \\
\text { Indicators (WDI) }\end{array}$ \\
\hline INFLATE & Inflation (annual \%) & $\begin{array}{l}\text { World Bank Development } \\
\text { Indicators (WDI) }\end{array}$ \\
\hline Govt_Consump & Government consumption & $\begin{array}{l}\text { World Bank Development } \\
\text { Indicators (WDI) }\end{array}$ \\
\hline POL & Combined Polity score & $\begin{array}{l}\text { PolityIV Project (Marshal et.al., } \\
\text { 2010) }\end{array}$ \\
\hline POP & Total population & $\begin{array}{l}\text { World Bank Development } \\
\text { Indicators (WDI) }\end{array}$ \\
\hline OPEN & $\begin{array}{l}\text { Openness (Imports as \% of GDP + } \\
\text { Exports as \% of GDP) }\end{array}$ & $\begin{array}{l}\text { World Bank Development } \\
\text { Indicators (WDI) }\end{array}$ \\
\hline GDPPC-Growth & $\begin{array}{l}\text { Gross Domestic Product per capita } \\
\text { growth (annual \%) }\end{array}$ & $\begin{array}{l}\text { World Bank Development } \\
\text { Indicators (WDI) }\end{array}$ \\
\hline
\end{tabular}

Source: Computed by the Authors

\subsection{Model Assumptions}

Robust standard errors were used to address serial autocorrelation and fixed-effect models attempted to compensate for extraneous influences that are common in panel studies. This model uses time-fixed effects by year, that correct for the omitted variable bias (Corrigan, 2013). For intermittent missing data, the closest available year of data was used, with a special focus on EITI-implementing countries. Normality of variables was examined. Where extreme outliers were detected, the log of the variables was used to address deviation from normality.

\subsection{Methodology}

We follow Corrigan (2013) and estimate equation (1) to provide empirical evidence on hypothesis $1\left(\mathrm{H}_{1}\right)$ and hypothesis $2\left(\mathrm{H}_{2}\right)$. The two statistical models have the same basic equation, but different dependent variables - GDP per capita for $\mathrm{H}_{1}$, and control of corruption for $\mathrm{H}_{2}$ The equation is as follows:

Equation 1:

$Y_{i t}=\beta_{0}+\beta_{1} R E S_{i t}+\beta_{2} E I T I_{-} M E M_{i t}+\beta_{3} R E S_{i t} \times E I T I_{-} M E M_{i t}+\beta_{4} Z_{i t}+\varepsilon$ 
Where: $Y_{i t}=$ GDP per capita for country $i$ at time $t$. $R E S_{i t}=$ resource endowment. EITI_MEM $M_{i t}$ $=$ EITI membership $(0=$ non-member, $1=$ member $)$. $Z_{i t}=$ control variables. $\varepsilon=$ error random, normally distributed and independent (Corrigan, 2013). The interaction term between $R E S_{i t}$ and EITI_MEM $M_{i t}$ is the main evaluated variable.

Table 2: Correlation results for the two hypotheses

\section{Hypothesis 1}

\begin{tabular}{|l|r|r|r|r|r|r|r|}
\hline & \multicolumn{1}{|c|}{ GDPPC } & \multicolumn{1}{|l|}{ INVEST } & INFLATE & Govt_Consump & POL & POP & OPEN \\
\hline GDPPC & 1 & & & & & & \\
\hline INVEST & $\mathbf{0 . 3 3 5 7}$ & 1 & & & & & \\
\hline INFLATE & $\mathbf{- 0 . 0 1 8 5}$ & -0.0202 & 1 & & & & \\
\hline Govt_Consump & $\mathbf{0 . 2 2 5 5}$ & 0.0061 & -0.0098 & 1 & & & \\
\hline POL & $\mathbf{0 . 0 1 7 3}$ & -0.0758 & -0.0421 & 0.1969 & 1 & & \\
\hline POP & $\mathbf{- 0 . 1 3 3 1}$ & -0.1205 & 0.0019 & 0.4121 & 0.0164 & 1 & \\
\hline OPEN & $\mathbf{0 . 3 2 9 4}$ & 0.3434 & 0.0310 & -0.0212 & -0.0040 & -0.1779 & 1 \\
\hline
\end{tabular}

\section{Hypothesis 2}

\begin{tabular}{|l|r|r|r|r|r|}
\hline & \multicolumn{1}{|l|}{ CoC } & Govt_Consump & POL & POP & GDPPC-Growth \\
\hline CoC & 1 & & & & \\
\hline Govt_Consump & $\mathbf{0 . 1 0 3 8}$ & 1 & & & \\
\hline POL & $\mathbf{0 . 4 6 2 7}$ & 0.1969 & 1 & & \\
\hline POP & $\mathbf{- 0 . 2 0 0 1}$ & 0.4121 & 0.0164 & 1 & \\
\hline GDPPC-Growth & $\mathbf{- 0 . 0 2 5 3}$ & -0.0058 & -0.0133 & -0.005 & 1 \\
\hline
\end{tabular}

GDP per capita: Gross Domestic Product per capita (constant 2010 US\$), CoC: Control of Corruption, EITImem: Dummy variable for EITI membership (1=intention, $0=$ no intention), RES: Resource dependence proxy (primary exports/merchandise exports), INVEST: Gross capital formation (\% of GDP), INFLATE: Inflation (annual \%), Government consumption: Govt_Consump, POL: Combined Polity score, POP: Total population, OPEN: Openness (Imports as \% of GDP + Exports as \% of GDP), GDPPC-Growth: Gross Domestic Product per capita growth (annual\%).

Source: Computed by the Authors

\section{Analysis}

\subsection{Introduction}

Two models were run separately to determine the effect of EITI membership on resource-rich states' economic growth and level of corruption. In line with the Corrigan (2013) study, a model-building approach was followed. This model starts with correlation table, to identify the most suitable variables for the analysis (Table 2 present the correlation result). This was followed by a simple regression, which include only one independent variable and evolves to the final model that includes all the independent and control variables. An interaction term between resource dependence and EITI membership was used in both models. Subsequently the main coefficients cannot be interpreted; instead, the interaction term coefficients are considered (Corrigan, 2013)

\subsection{Findings}

\subsubsection{GDP per capita}

Table 2 shows the leading results for the final model (model 10 in Table 3), including all relevant variables. The null hypothesis, that all coefficients on the independent variables are equal to zero, is rejected with extremely high confidence, above 99.99 per cent (F-test). The coefficient of the constant term is large and significant and is comparable to the t-statistic of the interaction term measured. However, the t-statistic for the interaction term is below 2, indicating moderate significance. The $P$-value of 0.066 is not significant at the $<0.05$ level but has moderate positive significance at the 0.1 level. It cannot therefore be completely ruled out that the results would not be observed under the null hypothesis, but there is some 
indication that EITI membership does have a positive influence on GDP per capita. This moderate significance is further supported by the R-Squared statistic of 46 per cent.

The model-building results in Table 3 provide additional support to some of the themes of this study. In model 1, resource dependence does have a negative impact on GDP per capita. It is however not very significant, which is plausible given that commodity-fuelled growth has occurred in multiple SSA countries, reducing the expected traditional impact of the resource curse. The introduction of EITI membership in model 2 does reverse the negative impact of resource abundance at the 0.05 significance level. The interaction term in models 3-9 is moderate to highly significant throughout the regressions and interacts positively with GDP per capita, supporting the findings in model 10.

Table 3: Hypothesis 1 - Main results

GDP per capita (Log) - regression results

\begin{tabular}{|l|r|r|r|l|r|}
\hline EITI membership effect on GDP per capita & \multicolumn{4}{l|}{} \\
\hline RES & Coef. & T-statistic & P>t & & \\
\hline EITImem & 0.04 & 0.52 & 0.606 & $\begin{array}{l}\text { R-squared } \\
\text { within }\end{array}$ & 0.4595 \\
\hline RES*EITImem & -0.16 & 0.08 & 0.061 & $\mathrm{~F}(8,41)$ & 15.34 \\
\hline Log (INFLATE) & $\mathbf{0 . 2 2}$ & $\mathbf{1 . 8 9}$ & $\mathbf{0 . 0 6 6}$ & Prob > F & 0.0000 \\
\hline Log (INVEST) & -0.00 & 0.28 & 0.778 & & \\
\hline Log (Govt_Consump) & 0.09 & -0.32 & 0.753 & & \\
\hline Log (POP) & 0.73 & 2.47 & 0.018 & & \\
\hline POL & -0.01 & 0.05 & 0.004 & & \\
\hline Log (OPEN) & & & 0.222 & & \\
\hline Constant & -6.27 & -1.91 & 0.063 & & \\
\hline
\end{tabular}

Note - GDP per capita: Gross Domestic Product per capita (constant 2010 US\$), EITImem: Dummy variable for EITI membership (1=intention, $0=$ no intention), RES: Resource dependence proxy (primary exports/merchandise exports), INVEST: Gross capital formation (\% of GDP), INFLATE: Inflation (annual \%), Government consumption: Govt_Consump, POL: Combined Polity score, POP: Total population, OPEN: Openness (Imports as \% of GDP + Exports as \% of GDP).

Source: Computed by the Authors 
Table 4: Hypothesis 1 - Model-building results

GDP per capita (Log) - regression results.

EITI membership effect on GDP per capita

\begin{tabular}{|c|c|c|c|c|c|c|c|c|c|c|}
\hline & 1 & 2 & 3 & 4 & 5 & 6 & 7 & 8 & 9 & 10 \\
\hline \multirow[t]{2}{*}{ RES } & -0.02 & 0.02 & -0.38 & -0.01 & -0.05 & -0.01 & -0.02 & -0.01 & -0.01 & 0.04 \\
\hline & $(-0.21)+$ & $(-0.24)+$ & $(-0.44)+$ & $(-0.13)+$ & $(-0.53)+$ & $(-0.14)+$ & $(-0.28)+$ & $(-0.14)+$ & $(-0.14)+$ & $(-0.52)+$ \\
\hline \multirow[t]{2}{*}{ EITI_MEM } & & 0.24 & 0.08 & 0.08 & 0.05 & -0.06 & 0.07 & -0.18 & -0.18 & -0.16 \\
\hline & & $(6.97)^{\star \star}$ & $(1.00)+$ & $(1.00)+$ & $(0.46)+$ & $(-0.93)+$ & $(0.88)+$ & $(-2.21)^{\star \star}$ & $(-2.21)^{\star \star}$ & $(0.08)^{*}$ \\
\hline \multirow[t]{2}{*}{ RES*EITI_MEM } & & & 0.22 & 0.21 & 0.26 & 0.21 & 0.21 & 0.26 & 0.26 & 0.22 \\
\hline & & & $(1.85)^{\star}$ & $(1.77)^{\star}$ & $(1.99)^{\star \star}$ & $(2.06)^{\star \star}$ & $(1.71)+$ & $(2.61)^{\star \star}$ & $(2.61)^{\star \star}$ & $(1.89)^{\star}$ \\
\hline \multirow[t]{3}{*}{ Log(INFLATE) } & & & & -0.13 & & & & & & 0.00 \\
\hline & & & & $(-0.88)+$ & & & & & & $(0.28)+$ \\
\hline & & & & 0.38 & & & & & & 0.78 \\
\hline \multirow[t]{3}{*}{ Log(INVEST) } & & & & & 0.02 & & & & & -0.02 \\
\hline & & & & & $(0.29)+$ & & & & & $(-0.32)+$ \\
\hline & & & & & 0.78 & & & & & 0.75 \\
\hline \multirow[t]{3}{*}{ Log(GOVT_CONSUMP) } & & & & & & 0.18 & & & & 0.09 \\
\hline & & & & & & $(6.08)^{* *}$ & & & & $(2.47)^{\star \star}$ \\
\hline & & & & & & 0.00 & & & & 0.02 \\
\hline \multirow[t]{3}{*}{$\mathrm{POL}$} & & & & & & & 0.01 & & & -0.01 \\
\hline & & & & & & & $(1.75)^{\star}$ & & & $(0.01)+$ \\
\hline & & & & & & & 0.09 & & & 0.22 \\
\hline \multirow[t]{2}{*}{ Log(POP) } & & & & & & & & 0.91 & & 0.73 \\
\hline & & & & & & & & $(5.06)^{* *}$ & & $(3.05)^{\star \star}$ \\
\hline \multirow{2}{*}{ Log(Open) } & & & & & & & & & 0.91 & \\
\hline & & & & & & & & & $(5.06)^{\star *}$ & \\
\hline \multicolumn{11}{|l|}{ T-stat in brackets } \\
\hline \multicolumn{11}{|c|}{ Significance level $\left.\left[<0.05::^{* *},<0.10:^{*},>0.10:+\right\}\right]$} \\
\hline \multicolumn{11}{|c|}{$\begin{array}{l}\text { Note - GDP per capita: Gross Domestic Product per capita (constant } 2010 \text { US } \$ \text { ), EITImem: Dummy variable for EITI membership (1=intention, 0=no } \\
\text { intention), RES: Resource dependence proxy (primary exports/merchandise exports), INVEST: Gross capital formation (\% of GDP), INFLATE: Inflation } \\
\text { (annual \%), Government consumption: Govt_Consump, POL: Combined Polity score, POP: Total population, OPEN: Openness (Imports as \% of GDP + } \\
\text { Exports as \% of GDP). }\end{array}$} \\
\hline
\end{tabular}

Source: Computed by the Authors 


\subsubsection{Corruption}

Table 6 shows the results for the final model (model 8 in Table 5). The result of the F-test does not reject the null hypothesis, as it is larger than the 0.1 significance level, indicating that the dataset might not have any predictive power. The result of the interaction term indicates a negative influence of EITI membership on corruption, but the result is not statistically significant.

The model-building results in Table 5 are also mostly insignificant. The interaction term between EITI membership and resource dependence on control of corruption is negative throughout, but not statistically significant.

Table 5: Hypothesis 2 - Main results

\begin{tabular}{|l|l|l|l|l|r|}
\hline $\begin{array}{l}\text { Control of Corruption - regression } \\
\text { results }\end{array}$ & & & \\
\hline $\begin{array}{l}\text { EITI membership effect on Control of } \\
\text { Corruption }\end{array}$ & Coef. & T-statistic & P>|t| & & \\
\hline RES & 0.10 & 0.47 & 0.642 & R-squared within & 0.0628 \\
\hline EITImem & 0.22 & 1.93 & 0.061 & F (7,42) & 1.16 \\
\hline RES*EITImem & $\mathbf{0 . 2 5}$ & $\mathbf{- 1 . 4 6}$ & $\mathbf{0 . 1 5 2}$ & Prob > F & 0.3436 \\
\hline Log(Govt_Consump) & 0.04 & 1.00 & 0.321 & & \\
\hline Log(POP) & 0.44 & -1.22 & 0.231 & & \\
\hline POL & 0.00 & 0.22 & 0.828 & & \\
\hline Log (GDPPC-Growth) & 0.01 & 0.98 & 0.335 & & \\
\hline Constant & 5.51 & 1.03 & 0.310 & & \\
\hline & & & & & \\
\hline
\end{tabular}

Source: Computed by the Authors 
Table 6: Hypothesis 2 - Model-building results

\begin{tabular}{|c|c|c|c|c|c|c|c|c|}
\hline \multicolumn{9}{|c|}{ Control of Corruption - regression results } \\
\hline \multicolumn{9}{|c|}{ EITI membership effect on Control of Corruption } \\
\hline & 1 & 2 & 3 & 4 & 5 & 6 & 7 & 8 \\
\hline \multirow{2}{*}{ RES } & 0.18 & 0.19 & 0.26 & 0.11 & 0.24 & 0.25 & 0.25 & 0.10 \\
\hline & $(1.5)+$ & $(1.54)+$ & $(1.59)_{+}$ & $(0.7)+$ & $(1.35)+$ & $(1.52)+$ & $(1.13)+$ & $(0.47)+$ \\
\hline \multirow[t]{2}{*}{ EITI_MEM } & & 0.03 & 0.23 & 0.10 & 0.28 & 0.25 & 0.33 & 0.22 \\
\hline & & $(0.56)+$ & $(1.24)+$ & $(0.82)+$ & $(1.59)+$ & $(1.33)+$ & $(1.5)+$ & $(1.93)^{\star}$ \\
\hline \multirow[t]{2}{*}{ RES*EITI_MEM } & & & -0.29 & -0.12 & -0.29 & -0.32 & -0.39 & -0.25 \\
\hline & & & $(-1.24)+$ & $(-0.70)+$ & $(-1.25)+$ & $(-1.36)+$ & $(-1.48)+$ & $(-1.46)+$ \\
\hline \multirow[t]{2}{*}{ Log(GOVT_CONSUMP) } & & & & -0.03 & & & & 0.04 \\
\hline & & & & $(-0.84)+$ & & & & $(1.00)+$ \\
\hline \multirow[t]{2}{*}{$\log (\mathrm{POP})$} & & & & & -0.20 & & & -0.44 \\
\hline & & & & & $(-0.93)+$ & & & $(-1.22)+$ \\
\hline \multirow[t]{2}{*}{$\mathrm{POL}$} & & & & & & 0.00 & & 0.00 \\
\hline & & & & & & $(0.44)+$ & & $(0.22)+$ \\
\hline \multirow[t]{2}{*}{ Log (GDPPC-Growth } & & & & & & & 0.00 & 0.01 \\
\hline & & & & & & & $(0.37)+$ & $(0.98)+$ \\
\hline \multicolumn{9}{|l|}{ T-stat in brackets } \\
\hline \multicolumn{9}{|c|}{ Significance level $\left.\left[<0.05^{* *},<0.10:^{*},>0.10:+\right\}\right]$} \\
\hline \multicolumn{9}{|c|}{$\begin{array}{l}\text { Note - CoC: Control of Corruption, EITImem: Dummy variable for EITI membership (1=intention, } 0=\text { no intention), RES: } \\
\text { Resource dependence proxy (primary exports/merchandise exports), Government consumption: Govt_Consump, POL: } \\
\text { Combined Polity score, POP: Total population, GDPPC-Growth: Gross Domestic Product per capita growth (annual\%). }\end{array}$} \\
\hline
\end{tabular}

Source: Computed by the Authors 


\subsection{Result}

The statistical analysis of 46 countries in SSA shows that EITI membership and its statistical interaction with resource dependence have a moderately positive effect on reducing the resource curse in implementing countries, by increasing GDP per capita. The results support the findings of Corrigan (2013); however, the positive effect of EITI membership in SSA is less significant than in the rest of the world. The lower significance is possibly due to the overall weak governance that plagues the region, which reduces the effectiveness of standards like the EITI, as transparency and accountability measures are most effective when there are checks and balances and a strong civil society that has the ability to act. The analysis found that resource dependence does not have a significant negative effect on economic growth, which does not conform to the traditional resource curse literature. The results do not indicate that EITI membership has no specific beneficial effect on levels of corruption in the region. This supports the findings of Corrigan (2013), who found no significance for the interaction between control of corruption and EITI membership. The consistently negative (however statistically insignificant) interaction between EITI membership and control of corruption runs counter to the expected hypothesis and empirical literature. A potential explanation for this phenomenon is a negative selection bias for EITI-implementing countries, which tend to have high levels of corruption to begin with. This is reflected by Botswana and South Africa not being members of the EITI, even though they are two of the most advanced democracies in the region. Corruption research traditionally suffers from indicators that do not capture the full effect of the nature of corruption in a given country. Current corruption measures, including the one used in this research assignment, capture perceived corruption instead of objective levels of corruption and tend not to vary significantly over time. The EITI could potentially be considered a "band-aid" solution that addresses some of the symptoms in resource governance without really addressing some of the causes, and its ability to fight corruption is limited to particular corruption areas (Corrigan, 2013). Research in this area could potentially benefit from using different measurements of corruption that parse out factors that are more or less affected by frameworks such as the EITI.

The central thesis of this study, that collective action through EITI membership and information disclosures can reduce corruption and subsequently indirectly reduce the harmful effect of resource abundance on economic growth, is not fully supported. The EITI potentially fails to address complex linkages and power relations between stakeholders, especially state manipulation of data and disclosure output, which undermines the effective mobilisation of collective action and its ability to hold government to account (Smith et al, 2012). As noted by Hilson and Maconachie (2009), the EITI has diagnosed the challenge of resource abundance and corruption in SSA "far too superficially", with some governments merely posturing and not implementing governance reforms. Examples of this are Chad (current member) and Equatorial Guinea (delisted in 2010), which remain some of the most oppressive regimes in the world (Hilson and Maconachie, 2009). Although evidence for this indirect effect is not visible, the direct effect of EITI membership on economic growth has gained some support. This study supports the likelihood that membership of international organisations signals to investors that the government is committed to reforms, and could lead to increased foreign investment and aid flows. If more money is coming into the country and less resource revenue is flowing out illicitly due to oversight by civil society, the benefit of EITI membership could be substantial. Even though the corruption perception levels remain high, more funds being available for spending on infrastructure and human development (health and education) does provide some validation for the implementation of the standard. 


\section{Conclusion}

A pooled cross-sectional panel study was performed on the 46 countries in SSA based on the World Bank regional definition, for the period 1996 to 2016. The study identified membership of the EITI has a positive effect on GDP per capita in SSA. Corruption levels remain high in the region and are not shown to be affected by EITI membership. These results indicate that the EITI has potential value and should continue to be used as a mechanism to increase transparency in the resource sector.

The implementation period for most member countries is still in its infancy. The success of the EITI will therefore be better assessed after a period of time. The credibility of the standard will be enhanced by convincing OECD countries, as well as some other richer economies in SSA (Botswana and South Africa), to join the EITI and use their existing institutional quality to set the benchmark for other implementing members. There is large scope for capacity-building across the standard, where the more developed nations can use approximation through membership to enhance the ability of less developed nations to hold their governments to account by empowering civil society and aligning local EITI frameworks with regional best practices.

Further research in this area is required once the EITI has had more time to develop and members to embed knowledge into their local frameworks. The use of alternative measurements that capture objective corruption could be beneficial in strengthening the link between the EITI and good governance. Another area of research that could be further explored is the effect of EITI membership on the value of illicit financial flows. Vast amounts of government resource revenue have flooded out of SSA illicitly, which could be countered by the keen eye of CSOs and the expansion of institutional transparency measures.

\section{References}

Bauhr, M., Grimes, M. and Harring, N. 2010. Seeing the state: The implications of transparency for societal accountability. University of Gothenburg: Quality of Government Institute Working Paper Series 2010:15.

Corrigan, C.C. 2013. Breaking the resource curse: Transparency in the natural resource sector and the extractive industries transparency initiative. Resources Policy 40, pp.17-30.

David-Barret, L. and Okamura, K. 2013. The transparency paradox: Why do corrupt countries join EITI? ERCAS Working Paper No. 38. Berlin: European Research Centre for Anticorruption and State-Building.

Dimant, E., \& Tosato, G. (2018). Causes and effects of corruption: what has past decade's empirical research taught us? A survey. Journal of Economic Surveys, 32 (2), pp. 335-356.

Fenster, M. 2005. The opacity of transparency. lowa Law Review 91 (3), pp. 885-949.

Fisman, R. and Golden, M.A. 2017. Corruption: What everyone needs to know. New York: Oxford University Press.

Geldenhuys, A.F., Ajuwon, O.S., and Graham, M., 2020. Resource curse and EITI Membership effect on The Economic Growth and Corruption in sub-Saharan Africa: Part I - A Theoretical Review. Oradea Journal of Business and Economics, 5 (1), pp.18-28.

Hilson, G. and Maconachie, R. 2009. Good governance and the Extractive Industries in sub-Saharan Africa. Miner. Process. Extr. Metall. Rev. 30 (1), pp. 52-100.

Huntington, S.P. 1968. Political order in changing societies. New Haven: Yale University Press.

Islam, R., 2006. Does more transparency go along with better governance? Economics \& Politics, 18 (2), pp.121-167.

Karl, T. L. 1997. The paradox of plenty: Oil booms and petro-states. Berkeley and Los Angeles: University of California Press. 
Kasekende, E., Abuka, C. and Sarr, M. 2016. Extractive Industries and corruption: Investigating the effectiveness of EITI as a scrutiny mechanism. Resources Policy 48 (C), pp. 117-128.

Kaufmann, D., Kraay, A. and Mastruzzi, M. 2010. The worldwide governance indicators: Methodology and analytical issues. Policy Research Working Paper Nr.5430. The World Bank Development Research Group, Macroeconomic and Growth Team.

Kolstad, I. and Wiig, A. 2008. Is transparency the key to reducing corruption in resource-rich countries? World Development, 37 (3), pp. 521-532.

Leff, N.H. 1964. Economic development through bureaucratic corruption. American Behavioral Scientist 8:8-14. Reprinted in A.J. Heidenheimer, M. Johnston \& V.T. LeVine (Eds) 1989. Political corruption: A handbook. Oxford: Transaction Books, pp. 389-403.

Leite, C.A. and Weidmann, J. 1999. Does Mother Nature corrupt? Natural resources, corruption and economic growth. Working Paper WP/99/85. International Monetary Fund. Mejía Acosta, A. 2013. The impact and effectiveness of accountability and transparency initiatives: The governance of natural resources. Development Policy Review, 31, pp. 89105.

Méon, P. and Sekkat, K. 2005. Does corruption grease or sand the wheels of growth? Public Choice, 122, pp. 69-97.

Nwapi, C. 2014. Enhancing the effectiveness of transparency in Extractive Resource Governance: A Nigerian case study. Law and Development Review, 7 (1), pp. 23-47.

Ross, M.L. 1999. The political economy of the resource curse. World Politics, 51 (2), pp. 297-322.

Rothstein, B. and Holberg, S. 2011. Correlates of corruption. Working Paper Series 2011:12. University of Gothenburg: The Quality of Government Institute.

Sachs, J.D. and Warner, A.M. 1995. Natural resource abundance and economic growth. Cambridge, MA: Centre for International Development and Harvard Institute for International Development.

Sachs, J.D. and Warner, A.M. 2001. The curse of natural resources. European Economic Review. 45 (4-6), pp. 827-838.

Smith, S.M., Shepherd, D.D. and Dorward, P.T. 2012. Perspectives on community representation with the Extractive Industries Transparency Initiative: Experiences from South-East Madagascar. Research Policy 37, pp. 241-250.

\section{Bio-Note}

Geldenhuys Andries Francois (Mr) holds a Master's degree in Development Finance from the University of Stellenbosch Business School, South Africa, and works at Transparency International, a leading anti-corruption NGO, in Berlin, Germany. He is also a certified Chartered Accountant [CA(SA)].

Ajuwon Oluseye Samuel (Dr) is a lecturer of economics at the University of Lagos, Nigeria, with a PhD in Development Finance from the University of Stellenbosch Business School, South Africa. His area of research is in macroeconomics, international finance, and development finance, with a special focus on financing small businesses.

Graham Michael (Prof) is the Programme Head, Development Finance. He was previously Associate Professor of Finance at Stockholm Business School in Sweden before joining USB. Prof Graham's research interest lies in empirical corporate finance, corporate governance and financial markets. He teaches Corporate Finance, Structured Finance, Infrastructure Finance and International Finance and has extensive and international teaching experience, having taught in Australia, Finland and Singapore. 


\section{APPENDIX A}

\section{Table A1: List of EITI Members in SSA}

\begin{tabular}{|c|c|c|c|}
\hline Country & $\begin{array}{l}\text { Date of official } \\
\text { membership }\end{array}$ & $\begin{array}{l}\text { Date of joining } \\
\text { intention }\end{array}$ & Status \\
\hline Burkina Faso & 2009 & 2007 & $\begin{array}{l}\text { Yet to be assessed against } 2016 \\
\text { standard }\end{array}$ \\
\hline Cameroon & 2007 & 2005 & $\begin{array}{l}\text { Yet to be assessed against } 2016 \\
\text { standard }\end{array}$ \\
\hline $\begin{array}{ll}\text { Central African } \\
\text { Republic }\end{array}$ & 2011 & 2007 & $\begin{array}{l}\text { Suspended due to political } \\
\text { instability }\end{array}$ \\
\hline Chad & 2007 & 2007 & $\begin{array}{l}\text { Yet to be assessed against } 2016 \\
\text { standard }\end{array}$ \\
\hline Cote d'Ivoire & 2008 & 2007 & $\begin{array}{l}\text { Yet to be assessed against } 2016 \\
\text { standard }\end{array}$ \\
\hline $\begin{array}{l}\text { Democratic } \\
\text { Republic } \\
\text { Congo }\end{array}$ & 2008 & 2005 & $\begin{array}{l}\text { Yet to be assessed against } 2016 \\
\text { standard }\end{array}$ \\
\hline Ethiopia & 2014 & 2009 & $\begin{array}{l}\text { Yet to be assessed against } 2016 \\
\text { standard }\end{array}$ \\
\hline Ghana & 2010 & 2003 & Meaningful progress \\
\hline Guinea & 2007 & 2005 & $\begin{array}{l}\text { Yet to be assessed against } 2016 \\
\text { standard }\end{array}$ \\
\hline Liberia & 2009 & 2007 & Meaningful progress \\
\hline Madagascar & 2008 & 2008 & $\begin{array}{l}\text { Yet to be assessed against } 2016 \\
\text { standard }\end{array}$ \\
\hline Malawi & 2015 & 2014 & $\begin{array}{l}\text { Yet to be assessed against } 2016 \\
\text { standard }\end{array}$ \\
\hline Mali & 2007 & 2006 & Meaningful progress \\
\hline Mauritania & 2007 & 2005 & Meaningful progress \\
\hline Mozambique & 2009 & 2008 & Meaningful progress \\
\hline Niger & 2007 & 2005 & $\begin{array}{ll}\begin{array}{l}\text { Inadequate } \\
\text { (suspended) }\end{array} & \text { progress } \\
\end{array}$ \\
\hline Nigeria & 2009 & 2008 & Meaningful progress \\
\hline $\begin{array}{l}\text { Republic of } \\
\text { Congo }\end{array}$ & 2007 & 2004 & $\begin{array}{l}\text { Yet to be assessed against } 2016 \\
\text { standard }\end{array}$ \\
\hline $\begin{array}{l}\text { São Tomé and } \\
\text { Príncipe }\end{array}$ & 2012 & 2005 & Meaningful progress \\
\hline Senegal & 2013 & 2012 & $\begin{array}{l}\text { Yet to be assessed against } 2016 \\
\text { standard }\end{array}$ \\
\hline Seychelles & 2014 & 2013 & $\begin{array}{l}\text { Yet to be assessed against } 2016 \\
\text { standard }\end{array}$ \\
\hline Sierra Leone & 2008 & 2006 & $\begin{array}{l}\text { Yet to be assessed against } 2016 \\
\text { standard }\end{array}$ \\
\hline Tanzania & 2009 & 2008 & Meaningful progress \\
\hline Togo & 2010 & 2009 & $\begin{array}{l}\text { Yet to be assessed against } 2016 \\
\text { standard }\end{array}$ \\
\hline Zambia & 2009 & 2008 & Meaningful progress \\
\hline
\end{tabular}

Source: Computed by the Authors 